\title{
Adapting the ordre public and morality exclusion of European patent law to accommodate emerging technologies
}

\author{
Patent law's existing public policy exclusion should be reinterpreted and a new method introduced for assessing the \\ moral and public policy implications of commercializing emerging technologies.
}

$\mathrm{n}$ recent years, genetic and other emerging technologies in the life sciences have put the patent system under increasing strain. To understand the reasons for this, it is necessary to consider the nature of emerging technologies and how they differ from non-emerging (established) technologies. Five key aspects distinguish them: radical novelty, relatively fast growth, coherence, prominent impact, and uncertainty and ambiguity; with the first (radical novelty) and last (uncertainty and ambiguity) being especially high in the early stages of an emerging technology's development ${ }^{1}$.

The implications for patent law of these aspects of emerging technologies are profoundly ambivalent. On the one hand, they make the technologies good candidates for patent protection. For example, radically novel inventions are more likely to satisfy the patentability requirements of novelty and inventive step (non-obviousness). In addition, inventions that produce a prominent impact, in the sense of being perceived to change the status quo, are more likely to satisfy the patentability requirement of industrial applicability (utility) and foster the optimism that emerging technologies have been noted to attract. Added to this is the tendency of patent offices and courts to support the patenting of uncertain and ambiguous technologies in resource-intensive fields such as biotech owing to their dependence on venture capital to be fully developed and commercialized ${ }^{2}$.

Countering these factors in favor of patenting emerging technologies is a significant factor against: skepticism regarding the truth-value of a patent applicant's formal claims engendered by the technology's uncertainty and ambiguity. In Europe, this explains the recent recognition by patent offices and courts of a so-called 'plausibility' requirement ${ }^{3-9}$. As stated by the European Patent Office (EPO), " $[t]$ he definition of an invention as being a contribution to the art, i.e., as solving a technical problem and not merely putting forward one, requires that it is at least made plausible by the disclosure in the application that its teaching solves indeed the problem it purports to solve." Inquiring into the plausibility of a patent applicant's claims underlines that, however novel a technology, and however exciting its potential applications or underlying scientific shift, it must be sufficiently developed to satisfy the formal 'technical' requirements of patentability: the existence of an invention (in the sense of a technical teaching or contribution to the art) that is new, inventive and industrially applicable, as well as sufficiently described in the patent document to enable its performance by a notional skilled addressee. However, while 'plausibility' may be useful in underlining these technical requirements of patentability, it misses entirely the non-technical requirement of European patent law, expressed in Article 53(a) of the European Patent Convention (EPC) and reproduced in Article 6(1) of the European Union Biotech Patenting Directive, that the commercial exploitation of an invention must not be contrary to morality or ordre public, a term used interchangeably in European Union legislation with public policy ${ }^{10}$. And this is unsurprising, since the focus of plausibility inquiries is on the truth value of the statements an applicant is required to make when seeking protection and, in its current interpretation at least, Article 53(a) does not require any positive statements by an applicant the truth value of which might be subjected to scrutiny.

Indeed, rather than undermining a claim of patentability, the uncertain and ambiguous nature of an emerging technology will support it by protecting it from challenge under Article 53(a) in two ways. The first is by depriving opponents of the evidence they need to establish that the effects of patenting the technology would be contrary to morality or public policy ${ }^{11}$. The second is by focusing attention on the actual properties of the technology and the history of its invention when assessing the morality or public policy of its patenting owing to the uncertainty and ambiguity of its future applications (and the difficulty therefore of assessing them $)^{12}$.

This effect of technological uncertainty and ambiguity is exacerbated by several features of the EPO's current interpretation of the public policy and morality exclusion. One is its narrow definition of ordre public as covering only "the protection of public security and the physical integrity of individuals as part of society," including the environment ${ }^{11}$. Another is its requirement that opponents of a patent bear a heavy burden of demonstrating that the patent would offend morality or public policy, including by presenting "conclusive evidence" that its risks to public policy outweigh its benefits ${ }^{11}$. And a third is its direction that the economic effects of a patent be ignored when assessing an Article 53(a) objection ${ }^{13}$.

This approach of the EPO to Article 53(a) is incoherent, unduly restrictive, and blind to the regulatory challenges presented by emerging technologies in the current social and political context particularly. By limiting a central site for public participation in the patent system, it is also undemocratic and reinforces the interpretive hold of patent officials and inventors over the system ${ }^{14,15}$. For these reasons, it should be revisited.

The starting point for revisiting the approach to Article 53(a) must be the concepts of ordre public and morality themselves. These were derived by the early framers of the European patent system from their own (continental) legal systems with the intention of being given a European meaning by the EPO. Consistent with this intention, Article 53(a) states that the commercial exploitation of an invention "shall not be deemed to be [contrary to ordre public or morality] merely because it is prohibited by law or regulation in some or all of the Contracting States." Properly conceived, "public policy" denotes 
formal legislative or other democratically derived norms for implementation by a legitimate political authority in support of the public interest ${ }^{16,17}$. And "morality", in the sense of "public morality" particularly, denotes the unwritten ethical convictions of a certain (political) community ${ }^{11}$. On this view, the questions raised by Article 53(a) should be whether commercializing a given technology would be contrary to European legislative or otherwise democratically established policy (i.e., public policy) or norms accepted as fundamental to European society (i.e., public morality). And these cannot be answered without regard to the likely economic effects of patenting the technology, be they increasing the costs of accessing the technology; requiring the reorganization of diagnostic, research or other activities to accommodate its patenting; or something else ${ }^{18}$.

That leaves the EPO's blindness to the regulatory challenges presented by emerging technologies in the current environment, reflected in its method of assessing Article 53(a) objections to a patent. In the case of a public policy objection, that method involves identifying and weighing the likely risks and benefits to society of granting a patent for the technology $y^{19}$. Less clear is the method for assessing morality-based objections. Recent decisions suggest that for objections based on human dignity, there is no risk assessment. If the objection is well-founded, in the sense that patenting the technology could affect respect for human dignity, the application will be rejected in recognition of the importance of human dignity as a moral value to European culture and civilization. ${ }^{12,20,21}$

Regardless of the basis for the objection, a distinction should be recognized in the context of Article 53(a) EPC (and Article 6(1) of the Biotech Patenting Directive) between emerging and non-emerging technologies and a different approach adopted for subject matter falling within the former category. This is consistent with the growing recognition of "emerging technologies" as a discrete category of technology that raises special policy and ethical issues, including for patenting. For example, the so-called 'IP5' - the world's five largest patent offices, responsible between them for granting approximately $85 \%$ of the world's patents - are considering how to harmonize their approach to emerging technologies ${ }^{22}$ while social scientists debate the nature of emerging technologies in recognition of that category's increased importance in different areas of policy-making ${ }^{1}$.

Sociological scholarship also reflects the paradigm shift in regulatory thinking owing to profound changes in the technological and sociopolitical environment over recent decades. These include the accelerating pace of technological change and increased value of technologies; the tensions in geopolitical relations and shift in geopolitical power from West to East; the growing influence of non-state actors and diminished importance of the Westphalian state in regulating social and economic behavior; and declining individual and social stability created by environmental destruction, attacks on traditional media, and the withering of traditional democratic values and safeguards, among other things. In areas outside intellectual property, including environmental protection particularly, these changes have led to a rejection of traditional methods of assessing technological risk and the adoption in their place of a precautionary method of risk assessment instead $^{23}$. Within intellectual property, they have led to a reconception of the role of patents in the political economy ${ }^{24}$, but not to a reconception of methods of assessing the risks and benefits of granting them (but see ref. ${ }^{25}$ ). In the context of Article 53(a) and emerging technologies especially, this imperviousness to the insights of regulatory theory is difficult to defend.

Hence I argue that if patent law is to take seriously the regulatory challenges of emerging technologies in the current environment, an important first step is to embrace the central insights of precautionary theory by accepting each of the following:

1. Technological uncertainty and ambiguity are not an appropriate reason for postponing regulatory intervention, including intervention in patent negotiation and granting processes.

2. Traditional evidence-based methods of assessing the risks to morality and public policy of commercializing a technology are inappropriate in the case of emerging technologies.

3. For emerging technologies, risk assessment of the type required by Article 53(a) necessitates an epistemic and deliberative process aimed at recognizing and confronting the uncertain consequences of new technologies and their implications for society.

In relation to how this might be achieved in practice: the most straightforward way would also be the most appropriate. The EPO (or its parent body, the European Patent Organization) and the 38 EPC Contracting States should introduce through Article 53(a) and equivalent domestic legal provisions a version of the risk assessment model proposed in 2016 and supported for adoption in other regulatory contexts ${ }^{26,27}$. This would involve creating a special morality and public policy triage system within the EPO and domestic patent offices to screen all patent applications for a predefined class of emerging technologies for certain threats, and subjecting applications identified as meriting it to full precautionary risk assessment. In the course of the initial screening, the question asked should be whether commercializing the relevant technology would threaten morality or public policy - including patent policy, and its principle of encouraging and rewarding the public dissemination of socially beneficial technologies through the promise of limited monopolies - in a manner that is either certain (so as to require immediate rejection of the patent application) or scientifically uncertain or socio-politically ambiguous (so as to require a more detailed risk assessment). Any application identified as requiring further assessment should be subjected to a public hearing, involving diverse representation from relevant parts of industry, government, academia and wider society, including the general public, to appraise the nature and seriousness of the threat posed by patenting. Among the considerations included in the appraisal should be (i) the different possible (direct and indirect) results of commercializing the technology, (ii) the different ways of commercializing it, including the benefits and risks of commercializing it by means of a patent specifically, and (iii) the different forms of patenting, including the different ways in which the technology's contribution to the art might be conceived for patentability purposes and the patent monopoly limited (or otherwise) accordingly. This would enable full consideration of the social, economic, cultural, ethical and political significance of patenting an emerging technology to be considered at the outset, before any patents might be granted for it. A properly informed decision regarding the appropriateness of allowing the patent in some form or at all could then be made, having regard to accepted ethical norms of European citizens (morality) and legislative or other democratic actions in pursuit of the public interest (public policy), and following a precautionary and deliberative process informed by a plurality of scientific and non-scientific interests and expertise. In appropriate cases, a decision to grant a patent might also be subject to review by the relevant patent office after a certain period to take account of subsequent developments. Once again, this would be in keeping with European decision-making in other regulatory areas ${ }^{28}$. It would also be far 
superior to the current approach adopted by patent offices in Europe and elsewhere of granting patents for emerging technologies and hoping that the patent owners will exploit their rights in a manner that is both ethical and consistent with public policy ${ }^{29,30}$. And it would recognize the importance of Article 53(a) as a means by which citizens can participate in the patent system and have their concerns about specific technologies heard and addressed ${ }^{31}$.

\section{Conclusions}

The grant of a patent represents a regulatory intervention by the state to support the commercialization of a given technology. In all cases, it follows a process of negotiation between the patent office, representing the public, and the inventor or other patent applicant - hence the idea of patents as social contracts, negotiated on behalf of the public and in service of its interest. The focus of that negotiation is on the requirements of patentability and whether the relevant technology meets them sufficiently to merit and justify a limited monopoly.

In Europe, one of the patentability requirements is that commercializing the technology not offend morality or public policy. In the current era of accelerating biotechnological change and uncertainty, it is imperative that this requirement be fully implemented in the assessment of patent applications and the negotiation of patent monopolies. In the context of emerging technologies particularly, a precautionary and deliberative process of identifying the potential risks of patenting for morality and public policy should be introduced, with an emphasis on promoting the transparent and inclusive appraisal of the implications for society of granting monopolies for technologies whose applications and effects are malleable and difficult to predict.

As I have been writing this article, the coronavirus pandemic has swept the world, bringing the values of the patent and related incentive systems back into the spotlight amidst widespread public concern over the commercial practices they encourage in the pharmaceutical and other industries ${ }^{32}$. In so doing, it serves as a grim reminder of the insularity of modern patent systems and the dearth of opportunities they afford for public participation. If we are to take seriously the idea of patents as regulatory interventions by the state involving the issuance of social contracts negotiated on behalf of the public and in service of its interest, this insularity must be addressed. In Europe, the legislative and other means required to address it are already in place.

\section{Justine Pila ${ }^{\bowtie}$}

St Catherine's College, University of Oxford, Oxford, UK.

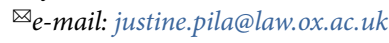

Published online: 11 May 2020

https://doi.org/10.1038/s41587-020-0504-5

\section{References}

1. Rotolo, D., Hicks, D. \& Martin, B. R. Res. Policy 44, 1827-1843 (2015).

2. Human Genome Sciences, Inc. v. Eli Lilly [2011] UKSC 51 [99][100] (Lord Neuberger).

3. T939/92 AgrEvo/Triazole Sulphonamides [1996] EPOR 171 (Tech. Bd App. 3.3.1, 12 September 1995) [2.6].

4. T609/02 AP-1 Complex/Salk Institute ECLI:EP:BA:2004 :T060902.20041027 (Tech. Bd App. 3.3.8, 27 October 2004) [10].

5. T1329/04 Johns Hopkins University School of Medicine/Growth Differentiation Factor-9 [2006] EPOR 8 (Tech. Bd App. 3.3.8, 28 June 2005) [20]-[22].

6. T1437/07 Botulinum Toxin for Treating Smooth Muscle Spasm/ Allergan ECLI:EP:BA:2009:T143707.20091026 (Tech. Bd App. 3.3.4, 26 October 2009) [26].

7. T0578/06 Pancreatic Cells/IPSEN ECLI:EP:BA:2011 :T057806.20110629 (Tech. Bd App. 3.3.4, 29 June 2011) [12]-[19].

8. T950/13 Bristol Myers Squibb/Dasatinib in the Treatment of Chronic Myelogenous Leukaemia ECLI:EP:BA:2017:T048816.20170201 (Tech. Bd App. 3.3.1, 1 February 2017) [3]-[4].

9. Warner-Lambert v. Actavis [2018] UKSC 56 [17]-[40] (Lord Sumption), [178]-[184] (Lord Hodges).

10. Article 16, Rome Convention on the Law Applicable to Contractual Obligations, OJ C 27/34 (1980).

11. T356/93 Plant Genetic Systems/Glutamine Synthetase Inhibitor (Opposition by Greenpeace) [1995] EPOR 357 (Tech. Bd App. 3.3.4, 21 February 1995) 366-372.

12. C-34/10 Brüstle v. Greenpeace eV [2011] ECR I-09821 (Grand Chamber, 18 October 2011).

13. G01/98 Novartis/Transgenic Plant [2000] EPOR 303 (Enlarged Bd App., 20 December 1999) [3.9].

14. Drahos, P. in The Global Governance of Knowledge: Patent Offices and Their Clients 285-317 (Cambridge Univ. Press, 2010).
15. Lee, M. in The Oxford Handbook of Law, Technology and Regulation (eds. Brownsword, R., Scotford, E. \& Yeung, K.) 620-644 (Oxford Univ. Press, 2017).

16. Corthaut, T. EU Ordre Public Ch. 1, I-06 (Kluwer Law International, 2012)

17. Waldron, J. Philos. Public Aff. 22, 3-30 (1993).

18. T1213/05 Breast and Ovarian Cancer/University of Utah ECLI:EP :BA:2007:T121305.20070927 (Tech. Bd App. 3.3.4, 27 September 2007) [52].

19. T19/90 Harvard/Onco-mouse [1990] EPOR 501 (Tech. Bd App. 3.3.2, 3 October 1990) [5].

20. G2/06 Use of Embryos/WARF ECLI:EP:BA:2008 :G000206.20081125 (Enlarged Bd App., 25 November 2008).

21. Article 1, Charter of Fundamental Rights of the European Union, OJ C 326/391 (2000).

22. EPO. World's five largest patent offices agree on joint task force for emerging technologies and AI (13 June 2019); https://www. epo.org/news-issues/news/2019/20190613a.html

23. Principle 15, 1992 Rio Declaration on Environment and Development, UN Doc A/CONF 151/26 (vol. I), 31 ILM 874 (1992) (14 June 1992).

24. Gurry, F. Re-thinking the role of intellectual property (WIPO speech, August 2013); https://www.wipo.int/export/sites/www/ about-wipo/en/dgo/speeches/pdf/dg_speech_melbourne_ 2013.pdf

25. Li, P. Health Technologies and International Intellectual Property: A Precautionary Approach (Routledge, 2014).

26. Science Communication Unit, UWE, Bristol. The precautionary principle: decision-making under uncertainty. Science for Environment Policy Future Brief 18 (European Commission, 2017); https://ec.europa.eu/environment/integration/research/ newsalert/pdf/precautionary_principle_decision_making_under uncertainty_FB18_en.pdf

27. Stirling, L. in The Oxford Handbook of Law, Technology and Regulation (eds Brownsword, R., Scotford, E. \& Yeung, K.) 645-669 (Oxford Univ. Press, 2017)

28. SH v. Austria App. No. 57813/00 [2011] ECHR 1878 (Grand Chamber, 3 November 2011) [118].

29. Guerrini, C. J., Curnutte, M. A., Sherkow, J. S. \& Scott, C. T. Nat. Biotechnol. 35, 22-24 (2017).

30. Baltimore, D. et al. Science 348, 36-38 (2015).

31. Black, J. in Law and Human Genetics: Regulating a Revolution (eds Brownsword, R., Cornish, W. R. \& Llewelyn, M.) 29-68 (Hart Publishing, 1998).

32. Mancini, D. P. Gilead criticized over 'orphan status' for potential virus treatment. Financial Times (24 March 2020); https://www. ft.com/content/9fea4flc-6dba-11ea-89df-41bea055720b

\section{Acknowledgements}

This article was first presented in November 2019 at a workshop entitled "Patents and Emerging Technologies" organized by N. Hawkins as part of a wider project on the impact of patents on translational research. The author is grateful to Prof. Hawkins for the invitation and to participants for questions and comments. She also thanks P. Li for bringing to her attention Prof. Li's book-length analysis of a precautionary approach to the issue of compulsory drug licensing in the early stages of a national public health emergency ${ }^{25}$.

Competing interests

The author declares no competing interests. 